\title{
The Peacebuilding of the Chittagong Hill Tracts (CHT), Bangladesh: Donor-Driven or Demand-Driven?
}

\author{
Anurug Chakma
}

\begin{abstract}
The decade-long low-intensity armed conflict in the Chittagong Hill Tracts (CHT) that surfaced soon after the independence of Bangladesh (1971) due to the failure of the state-building project ended with the CHT Accord which was signed in 1997 between the government of Bangladesh and the Parbattya Chattagram Jana Sanhati Samiti (PCJSS). This study uses qualitative research methods to explore the fundamental research question of who is in the driver's seat of the post-accord CHT peacebuilding process. A mostly top-down approach to peacebuilding has been used in the CHT due to an entirely donor-driven peacebuilding partnership between local and international stakeholders. Under this asymmetric power structure, the marginalization of local ownership is expected to produce unintended results in the peace process.
\end{abstract}

Keywords international stakeholders, peacebuilding intervention, donor-driven partnership, local ownership, asymmetric power structure

\section{Introduction}

Peacebuilding should not be viewed as a package of incentives and initiatives. It should not be a five-year package, and it is not all about money. Rather local institutions should be reformed in addition to the establishment of better coordination among them, as is required for facilitating the peacebuilding process (Interview with a local informant on June 19, 2016 in Bandarban).

The Chittagong Hill Tracts (CHT), bordered by India and Myanmar, is situated in the south-eastern corner of Bangladesh where eleven indigenous communities ${ }^{1}$ have been living for generations (Ahsan and Chakma 1989). They enjoyed autonomy during British colonial rule in accordance with the CHT Regulations promulgated in 1900 (Amnesty International 2013; Chakma 2010; Zahed 2013, 97-98). Later it was annexed into Pakistan per the controversial decision of the 
Radcliffe Boundary Commission (Chittagong Hill Tracts Commission 1991; Chakma 2010), and this eventually led to the rise of intra-state conflict under the rule of Pakistan due to the withdrawal of its special status as an "excluded area" and the construction of Kaptai hydro-electricity power plant, the largest development catastrophe in the history of the region which resulted in a massive displacement of over 100,000 indigenous peoples (Ahsan and Chakma 1989). Shortly after the independence of Bangladesh (formerly East Pakistan) in 1971, the CHT conflict became intractable around a number of central incompatibilities such as citizenship, identity, and autonomy (Mohsin 1999, 63), and finally escalated into a protracted low-intensity armed conflict in 1977. This decadesold affair came to an end officially when the government of Bangladesh and the Parbattya Chattagram Jana Sanhati Samiti (PCJSS), on behalf of indigenous people, signed the CHT Accord in 1997 (Amnesty International 2013).

The CHT Accord has ushered in a new beginning in the CHT conflict by opening the door for local non-government organizations (NGOs) and international donors ${ }^{2}$ to design and execute multiple and mixed approaches to peacebuilding interventions in the areas of rehabilitating refugees and delivering health and education services (Gerharz 2002). The United Nations Development Programme Chittagong Hill Tracts Development Facility (UNDP-CHTDF) is the largest post-conflict reconstruction project undertaken by international stakeholders with a total of US\$ 160.05 million in funding. Basically, international actors have emphasized capacity-building for key local CHT institutions, ${ }^{3}$ community empowerment, delivery of essential services, and implementation of the CHT Accord (Chakma 2013). On the contrary, a number of local NGOs (currently there are fifty-two registered local NGOs) have flourished in the postAccord period. Most of them have been working with international stakeholders as local peacebuilding partners since the CHT Accord was signed (Mohsin 2003).

Ironically, there is a colossal gap between the principle of establishing local ownership over peacebuilding and the painful reality on the ground (Futamura and Notaras 2011; Cutillo 2007, 17, 41). This insightful observation is consistent with the peacebuilding process in the $\mathrm{CHT}$. As stated by an executive director of a leading local NGO:

External actors cannot define peace for the CHT; rather local people should do that from their own perspective. What I understand from the local perspective is that peace is the free movement of people, the opportunity to practice one's own culture, and protection from fear, violence, and insecurity (Interview with a local informant on June 24, 2016 in Rangamati).

Hence, this study addresses the fundamental research question of which actors (local NGOs or international stakeholders) are in the driver's seat in the peacebuilding process of the CHT. This paper is structured as follows: first, it 
discusses the methodology that has been used in this study. Second, it briefly illustrates the concept and theories of peace building. Third, it deals with the peacebuilding interventions of both local NGOs and international stakeholders in the CHT. Fourth, it explains how and who have designed these peacebuilding interventions, followed by the concluding section.

\section{Peacebuilding: Concept and Theories}

Johan Galtung first coined the term "peacebuilding" in 1976, but there is no universally agreed upon definition of peacebuilding. It has been defined by different interest-driven and ideology-oriented scholars in many ways (Cady 2014; Peou 2014, 39). Despite the debate around the concept of peacebuilding, it is now a prominent discourse in the international arena. Precisely speaking, it gained wide acceptability in the 1990s when Boutros Boutros-Ghali, the former Secretary-General of the United Nations (UN), reiterated it in the "Agenda for Peace." For Boutros-Ghali, peacebuilding refers to post-conflict interventions to help prevent a relapse into conflict and to support war-torn countries in establishing sustainable peace (Cady 2014). In other words, peacebuilding is a process which facilitates the transition from conflict to durable peace (Shinoda 2002, 33; Lederach 1997).

There are two major streams of peacebuilding: local peacebuilding and international peacebuilding. According to the perspective of international peacebuilding rooted in post-Cold War liberal project, the "international peacebuilding community" is composed of a myriad of actors ranging from states and international organizations to corporatations, civil society organizations, and individuals (Peou 2014, 39). Given the war-ravaged economic conditions and a shortage of conflict resolution skills and manpower at the local level, international assistance is needed to implement different large-scale projects for post-conflict reconstruction (Hellmuller 2014, 6-9). But international liberal peacebuilding has its limitations due to its exclusive focus on the "one-size-fits-all" approach and a downside in advancing democratization, institution-building, and economic development (Autesserre 2014; Peou 2014). Hence, peacebuilding interventions should prioritize community needs and local ownership as has been avowed in a large volume of documents including in a policy statement by the Organisation for Economic Co-operation and Development (OECD 1997). Most strikingly, the second half of the last decade brought institutional innovations in peacebuilding; for instance, the Peacebuilding Commission at the UN, the Conflict Prevention and Reconstruction Unit at World Bank, the Office of the Transition Initiative at the United States Agency for Development (USAID), the Peacebuilding Unit at the Canadian International Develpoment Agency (CIDA), the Conflict and Humanitarian Affairs Department at the UK Deparment for International 
Development (DFID), and the Informal Task Force on Conflict, Peace and Development Co-operation at the Organisation for Economic Co-operation and Development (OECD) (Doyle and Sambanis 2000; Boyce 2004; Tschirgi 2004, 10 11; Cutillo 2007, 77).

\section{Methodology}

This study has been carried out using the semi-structured in-depth interview method with documentary analysis. I interviewed twenty-one staff members from local NGOs and donor organizations in Dhaka and three districts of the CHT between June 16 and July 14, 2016. It is noteworthy that cultural and linguistic diversity, uneven socio-economic development, and different political atmospheres are discernible across three districts of the CHT, namely, Khagrachhari, Rangamati, and Bandarban. All of these contextual variations allowed me to cover diverse perceptions of local NGOs working all over the CHT. I have chosen this method since it is widely used; in particular, Hellmuller (2014) uses this method in his research on the contentious relations between local and international actors in the peacebuilding process in the Democratic Republic of Congo. Additionally, this method has credibility as an important qualitative research technique (Hammersley and Gomm 2008) as it is used to gain "both breadth of coverage across key issues, and depth of coverage within each" (Yeo et al. 2003, 148). I have used a purposive sampling method for selecting interviewees on the basis of their relevance to my research question. The sample size was not pre-determined and I continued to conduct interviews until I reached the saturation point (i.e. when no new insights emerge and taking into account time limitations). I have used the thematic analysis method for data analysis. Firstly, I carefully transcribed all the recorded interviews and then read all the transcripts. Secondly, I coded data manually and sorted different codes under the emerging themes. Finally, I refined all the collected themes based on the relevance to the research questions of this study.

\section{Peacebuilding Interventions: The Case of the CHT}

Prior to the discussion on who is in the driver's seat in designing and executing peacebuilding interventions in the $\mathrm{CHT}$, we should have an in-depth understanding of what peacebuilding interventions are in the context of the CHT. A respondent of this study defines peacebuilding interventions as providing support for mixed policing, conflict reduction, land dispute resolution, implementation of the CHT Accord, community development, and capacity-building of key local institutions (Interview with an international staff member of a donor organization on June 
11, 2016 over Skype). These various facets of peacebuilding interventions are illustrated below.

\section{Implementation of the CHT Accord}

The government of Bangladesh restricts the role of local NGOs in carrying out advocacy for human rights and implementation of the CHT Accord, although they have been allowed limited space to work on soft issues related to peacebuilding such as education, food security, health, natural resource management, etc. (Interview with a local informant on July 1, 2016 in Khagrachhari). On the contrary, international stakeholders directly influence the implementation of the CHT Accord in two separate ways. Firstly, they have established the United Nations Chittagong Hill Tracts Task Force (UNCHTTF) charged with harmonizing activities of all UN agencies working in the region. Secondly, the UNCHTTF collaborates with other donor partners, diplomatic missions, and the governments of other states to exert collective pressure on the government of Bangladesh to implement the Accord (Cunnington et al. 2014, 50). They create collective diplomatic pressure on the government of Bangladesh by reminding it of its legal obligations in accordance with international conventions and treaties related to the human rights of indigenous people (Interview with an international informant on June 24, 2016 in Rangamati). On the other hand, the role of international actors at the local and national levels for the implementation of the Accord can be conceptualized as follows:

The main focus of international stakeholders is to support the implementation of the Accord through organizing dialogues between different (national and local) actors, improving the quality of governance, and establishing coordination between the Ministry of Chittagong Hill Tracts Affairs (MoCHTA) and the Chittagong Hill Tracts Regional Council (CHTRC). This is the area of our contribution, although a lot of activities still need to be undertaken (Interview with an international informant on July 11, 2016 over Skype).

As argued by Cunnington et al. (2014, 50-51), international actors have been successful in organizing two top-level dialogues, which included members of the Parliamentary Caucasus on Indigenous Peoples (PCIP), a special adviser to the Prime Minister, MoCHTA, donors, and indigenous leaders, with the objective of outlining an action plan for the implementation of the Accord. Furthermore, the UNDP-CHTDF has facilitated a dialogue between the government, the PCJSS, and the CHTRC to reduce discord over the drafting of an amendment to the Land Dispute Resolution Act of 2001 (UNDP-CHTDF 2014, 9). In addition, the UNDP-CHTDF has contributed to mixed policing by integrating 212 indigenous police officers into twenty-five police stations in the CHT. In the area of law, the UNDP-CHTDF has organized two dialogues on how to harmonize the existing laws of the three Hill District Councils (HDCs) and other local government 
institutions to clarify the division of labor among local institutions (Cunnington et al. 2014, 50-51). Finally, the presence of international stakeholders, particularly the $\mathrm{UN}$, in the region has created confidence and a sense of security among local communities.

\section{Conflict Prevention}

Under the sensitive post-conflict reality, the role of local NGOs is basically confined to providing relief and emergency support to people affected by communal violence in the CHT (Interview with a local informant on June 23, 2016 in Rangamati). On the contrary, international stakeholders have directly intervened to prevent local tensions from escalating into large-scale violence. For instance, the UNDP-CHTDF has introduced an early warning system to reduce or prevent any type of communal conflict in the CHT from reaching the level of destructive conflict (Interview with an international informant on June 16, 2016 in Dhaka). In addition, international stakeholders have responded to large-scale violence and incidents that occurred earlier at different places in the region. For instance, the UNDP-CHTDF provided US\$ 40,000 and the Food and Agricultural Organization (FAO) distributed US\$250,000 to affected families to assist in their efforts to recover in the aftermath of the Taindong communal violence which resulted in the displacement of more than 2,000 indigenous families (UNDPCHTDF 2014, 10; Cunnington et al. 2014, 51-52).

The prevention of conflict is mostly reliant on the goodwill of political leaders since every violent incident in the $\mathrm{CHT}$ has a political background mixed with other social and economic issues (Interview with an international informant on July 11, 2016 over Skype). But the UNDP-CHTDF does not support any single political camp as it is neutral (Interview with a local informant on June 16, 2016 in Dhaka). It brings communities together at different meetings both at the district and sub-district levels. Further, it has formed a group of forty-seven peacemakers composed of representatives from different communities, including thirty-five women leaders, with the goal of establishing a common shared future for the CHT (Interview with an international informant on July 11, 2016 over Skype; Cunnington et al. 2014).

\section{Protection and Promotion of Human Rights}

State violence is visible in the CHT in addition to gross human rights violations by non-state actors. A total of 3,911 acres of land in the CHT was grabbed in 2014 alone by both state and non-state actors. Furthermore, 84,647 acres of land of indigenous peoples are now being illegally occupied. Compared to the two other districts, Bandarban, particularly the Lama sub-district, has experienced large-scale land grabs by different national corporations. This land grabbing induced insecurity has forced 210 indigenous families to migrate to Myanmar from the Alikadam-Thanchi Hills in the Bandarban district (Azad 2015). Local 
NGOs, with the support of international stakeholders, have undertaken different initiatives to protect human rights in the CHT. For example, three local NGOs, namely, Khagrapur Mohila Kalyan Samiti (KMKS), the Centre for Integrated Programme and Development (CIPD), and the Maleya Foundation (MF), organized a three-day workshop on conservation and management of village common forests (VCF) in Khagrachari in March 2014 (Maleya Foundation 2014). International stakeholders have been providing support to local NGOs since their engagement in the peace process. For instance, the DANIDA project on human rights and good governance has helped local communities protect a large portion of land from illegal acquisition. Beyond the land issue, local NGOs have also partnered with the United Nations Children Fund (UNICEF) on a project for adolescents which mainly focuses on preventing child marriage and child abuse by creating awareness about adverse social impacts of these practices and laws related to the prohibition of child marriage and child labor (Interview with a local informant on June 20, 2016 in Bandarban).

\section{Capacity-Building of Local Institutions}

Beyond the issues of the implementation of the CHT Accord and conflict reduction, international stakeholders have been providing capacity-building training, staffing, and logistical support to the CHTRC, MoCHTA, HDCs, traditional leadership, local NGOs, and community groups (Interview with an international informant on June 16, 2016 in Dhaka). For instance, the UNDPCHTDF has provided technical and logistical support by developing websites for three HDCs which are now circulating 65 percent of their official documents and reports online. This intervention by international stakeholders has contributed to the transparency and openness of these local institutions. Additionally, the UNDP-CHTDF has trained roughly 450 staff members for three HDCs and line departments on project management, proposal writing, and geographic information systems. Furthermore, it has contributed to the e-governance system of the MoCHTA by supplying information and communication equipment. It has also provided assistance to three traditional leadership groups in managing village common forests along with the financial support for the traditional festival of Raj Punna. ${ }^{4}$ Moreover, it has trained up seventy-two Headmen ${ }^{5}$ and Karbari ${ }^{6}$ from Mong and Bomang circles on the customary laws of the CHT (UNDPCHTDF 2014, 12-13).

\section{Community Development}

The UNDP-CHTDF has assisted approximately 100,730 families across three districts of the CHT under 3,257 PDCs (Village Development Committees in English) and 1,685 PNDGs (Village Women Development Groups in English). Each PDC was offered a grant worth as much as \$BDT 300,000 and each PNDG received an amount of \$BDT 200,000 for community-driven small-scale projects 
like cow rearing, fisheries, ginger production, etc. It also awarded extra funding to active PDCs for establishing rice banks and farmer schools (Cunnington et al. 2014, 33; Chakma 2013). These interventions by the UNDP-CHTDF have been successful in improving the living standards of locals (although this is contested). On the contrary, local NGOs have provided training to women with project funding. This training has helped many women from NGO-led grassroots committees to win local level elections over the last few years. This is a significant achievement in the area of community empowerment and has brought greater attention to the gender issue in the post-conflict environment of the CHT (Interview with a local informant on June 20, 2016 in Bandarban). As stated by a local:

We train and motivate women to work on agricultural projects and also create awareness among them to save money in the bank. We suggest they keep a portion of production for their families and sell the rest for generating income, and invest this income into the education and healthcare of their children (Interview with a local informant on July 4, 2016 in Khagrachhari).

In addition, local NGOs provide training on sewing machines to women. Now many women are earning income which is one of the remarkable positive outcomes of the peacebuilding efforts in the CHT (Interview with a local informant on June 24, 2016 in Rangamati). As the UNDP-CHTDF household survey reports, the income of households has increased by 19.3 percent since 2008. Furthermore, households that have utilized the 690 farmer field schools established in the region have seen their incomes rise by 63 percent and their food deficit decrease (Cunnington et al. 2014, 34-36).

\section{Service Delivery}

If I do not have rice and lentil to feed my children and also do not have regular monthly income to afford education for my children, I cannot live in peace. If I can fulfill my basic needs, then I can think of peace. So, poverty is the major challenge to peace (Interview with a local informant on June 20, 2016 in Bandarban).

This remark by a local is rooted in the history of deprivation of basic needs. A study reports that the infant mortality rate of the CHT is higher than the national average (Hossain 2013). Additionally, the socio-economic baseline survey conducted by Barakat et al. (2009) shows that 51 percent of respondents have no formal education. The indigenous Khumi community has ranked the highest in illiteracy at 88.4 percent, followed by the Mro at 86.6 percent and the Khyang community at 74.1 percent (ibid.). The UNDP-CHTDF has undertaken a number of initiatives to reduce poverty and provide essential services to local communities in the CHT. It has supported three HDCs in managing health 
services with 853 community health service workers and sixteen mobile medical teams who work in eighty satellite clinics (Cunnington et al. 2014). In addition, a total of 158 community skilled birth attendants work in remote areas of the region to provide health services to pregnant women and assist with safe deliveries. Furthermore, the UNDP-CHTDF has offered project funding to 315 primary schools administered by three HDCs along with fifteen community schools located in the Bandarban district of Naikhyongchari. More than 20,000 new students gained access to schooling in 2014 alone (UNDP-CHTDF 2014, 1620). Local NGOs have earned a positive reputation for their health and education programs in the $\mathrm{CHT}$, maintaining extensive collaboration with the Education and Health Departments of the government (Interview with a local informant on June 21, 2016 in Bandarban).

\section{The Peacebuilding of the CHT: Donor-Driven or Demand-Driven?}

The CHT Accord and the Rangamati Declaration emphasize the partnership between local NGOs and international stakeholders for promoting peace in the region (Interview with an international informant on June 25, 2016 in Rangamati). As expected, their partnership has continued for over a decade, but the imbalanced power structure has led to the central research question of this study: who is in the driver's seat in terms of designing peacebuilding interventions that are executed on the ground. This study provides a number of thought-provoking and insightful findings which are discussed in relation to the following broad themes with reference to secondary literature.

\section{Multiple and Mixed Approaches to Peacebuilding}

Most of the respondents in this study identified the bottom-up approach as the most efficient tool for designing peacebuilding interventions, rather than the topdown approach used in the CHT, since it can generate sustainable peace. This is done by encouraging the active involvement of local stakeholders who can address their local needs in a sustainable way (UN Secretary-General 2009).

My personal opinion is that the UNDP should incorporate local needs. The 'copy-paste system' will not work here since the CHT is different from other parts of the world in terms of geography, culture, and demography. I hope the UNDP will do it (Interview with an international informant on June 16, 2016 in Dhaka).

Local participation, local voices, local ownership, and local transparencyall these things are highly important for peacebuilding in the CHT. However, local ownership over the peacebuilding process can only be established through consultation with local NGOs, local civil society groups, and local leadership 
(Interview with an international informant on July 11, 2016 over Skype). Taking this issue into consideration, a very small number of international stakeholders conduct local needs assessments at the community or household level to identify appropriate interventions (Interview with an international informant on June 24, 2016 in Rangamati). Other studies also report that the UNDP-CHTDF carried out a "needs assessment" at the village level in the wake of project activities and a baseline household survey in 2009. The last one was conducted in 2012 (Cunnington et al. 2014, 26). After the needs assessment, the UNDP-CHTDF makes a project document and then approves the project. In the next phase, it calls for applications from local NGOs with whom they form partnerships. It is true that many local NGOs do not know about this process (Interview with a local informant on July 3, 2016 in Khagrachhari). In addition, the Asian Development Bank (ADB) also obliges local NGOs to consult with people at the PDC level to identify which interventions will be effective for their needs. After the consultation, local NGOs submit their local needs assessment reports to the regional project management office of the ADB (Interview with a local informant on June 20, 2016 in Bandarban). Additionally, the International Fund for Agricultural Development (IFAD) suggests that local NGOs go into the field and identify local needs through consultation workshops at the grassroots level before submitting a funding application (Interview with a local informant on June 23, 2016 in Rangamati).

However, a group of informants to this study suggest that an entirely opposite narrative from the bottom-up approach to peacebuilding is playing out currently in the CHT. Their central argument is that international stakeholders have consulted with the community on very few projects, and local participation was absolutely ignored in the majority of the post-conflict reconstruction projects. An international staff member of a donor organization also reports that international organizations basically design peacebuilding interventions for the CHT based on the availability of funds with a special focus on the interests and priorities of donors (Interview with an international informant on June 16, 2016 in Dhaka). The reality of peacebuilding in the CHT also reflects the opinions of Duckworth (2016) and Futamura and Notaras (2011), according to whom local priorities and needs do not get preference over the interests and motivation of donors. For example, an international stakeholder has recently called for project proposals on a village common forest, but local NGOs have to work with the donor according to the predetermined framework of this project. Above all, these international donors use local NGOs in the CHT as their vehicles by which they can reach their goals (Interview with a local informant on June 19, 2016 in Bandarban). This implies that local NGOs have structural constraints in defining local needs since they are bound to the donor's terms of reference. Consequently, most of the projects are not demand-driven and have failed to produce sustainable outcomes (Interview with a local informant on June 20, 2016 in Bandarban). One 
respondent summed up this experience in the following manner:

Local people assume that this is the UNDP cow. This is the UNDP goat. This is the UNDP well. They do not think this is our cow, our goat, or our well. This blatantly signifies that the UNDP has failed to grow a sense of ownership among local communities through its project activities (Interview with a local informant on June 23, 2016 in Rangamati).

The reality on the ground suggests that the sustainability of peacebuilding interventions depends on local ownership by creating motivation and a sense of responsibility at the community level (Haider 2009; Futamura and Notaras 2011; Hellmuller 2014; Gruener and Hald 2015). Many PDCs and PNDGs in the CHT have become dysfunctional after the phase out of the UNDP-CHTDF community empowerment projects due to the absence of local ownership (Interview with a local informant on June 23, 2016 in Rangamati). In this regard, peacebuilding in the CHT is similar to the case of Rwanda where donors installed a transitional justice system with good intent and impartiality, but ultimately the results were disastrous due to the incongruence between the project and the local historical and cultural context (Duckworth 2016).

Both approaches have positive and negative sides. The top-down approach fails to identify demand-driven context-specific peacebuilding interventions (Austere 2014; Hellmuller 2014), whereas the bottom-up approach cannot overcome the problem of elite capture (Haider 2009; Brabant 2010). In other words:

The bottom-up approach might be good and bad. It is bad when local people do not have previous experience on how to implement project interventions whereas international experts have this experience. In addition, the targeted beneficiaries become deprived of the project benefits due to the diversion or manipulation of the project by elites (Interview with an international informant on June 16, 2016 in Dhaka).

Hence, the mixed or hybrid approach to peacebuilding intervention might be more effective compared to the bottom-up and top-down approaches (Paris 2004; Mac Ginty 2011). However, the nature of the partnership ultimately depends on the interests of donors. There are diverse international donors with different visions and missions working in the $\mathrm{CHT}$, but few donors design their projects through consultation with local NGOs whereas the majority of them impose their decisions on local partners (Interview with a local informant on June 23, 2016 in Rangamati). Therefore, it can be concluded that peacebuilding interventions in the CHT are sometimes designed through a mixed method (hybrid approach), but the top-down approach is most prevalent. 


\section{One-Sided Accountability and the Primacy of Donors}

The MoCHTA and NGO Bureau of Bangladesh approve the projects of local NGOs based on the clearance certificate of intelligence units, the Deputy Commissioner, and the CHTRC (Interview with a local informant on June 21, 2016 in Bandarban). On the donor side, local NGOs sign a memorandum of understanding with international stakeholders based on an action plan for the delivery of services to the beneficiaries of the project. Donors not only give them targets, a time schedule, and funds for projects, but even come into the field to monitor whether pre-determined targets have actually been meet (Interview with a local informant on June 20, 2016 in Bandarban). Many donors give project funding to local NGOs in the CHT in installments to ensure quality with the rationale that local NGOs are provided all the installments for project funding based on the progress of implementation (Interview with a local informant on June 24, 2016 in Rangamati). At the community level, the accountability of local NGOs is ensured through consultation with villagers on what kinds of benefits they will get from the project (Interview with a local informant on June 18, 2016 in Bandarban). On the other hand, according to Cunnington et al. (2014) and Chakma (2013), the PDCs and PNDGs of the UNDP-CHTDF that have been functional and sustainable are those where local NGOs directly intervened. Despite the good intentions of international stakeholders, they are not accountable at the grassroots level, although they conduct consultations on peacebuilding interventions at the ministry and donor level (Interview with an international informant on June 16, 2016 in Dhaka). Finally, it can be argued that the accountability of local NGOs to international donors suggests that peacebuilding in the $\mathrm{CHT}$ is under the control of international donors.

\section{Donor-Driven Partnership}

Partnerships are based on mutual respect, good understanding, and collaboration. In the very beginning, the UNDP-CHTDF started its interventions with contracted partners, but it has entered into donor-driven partnerships over the last few years. Local NGOs in the CHT are now working only toward delivering goods to international donors. This is also observed in Indonesia and TimorLeste where donors work with local NGOs through three types of partnerships: contract partnerships, donor-driven partnerships, and networking partnerships (Dibley 2014). In a contract partnership, both actors fulfill targets of the project interventions quantitatively, but without quality since local NGOs do not have enough space to bring modalities into the project design as contractors. Hence, this type of partnership demoralizes local NGOs since they want to implement projects in the cheapest manner possible (Interview with a local informant on July 3, 2016 in Khagrachhari). In the opinion of another local informant of this study: 
The UNDP-CHTDF has created adverse consequences through the bidding and contract system. We local NGOs are now businessmen working for profit. The UNDP-CHTDF is also emphasizing the reduction of project costs, not the quality of deliverable goods (Interview with a local informant on June 18, 2016 in Bandarban).

In addition, when we talk about partnerships, we talk about who chooses whom as a partner. In the case of peacebuilding in the CHT, it is the international stakeholders who choose their local peacebuilding partners. But the question is how they select their local partners. In this regard, this study has uncovered two contrasting perspectives between local and international informants. According to an international informant, the UNDP-CHTDF has an expert team which assesses project proposals from local NGOs based on a scoring system. It gives the project to an NGO which scores highest in the competition (Interview with an international informant on June 24, 2016 in Rangamati). As explained by an international interviewee:

Firstly, we call for the funding application and then assess project proposals after getting applications from local NGOs. We choose experienced local NGOs, which have a presence at the sub-district level, for the project funding. We look at the capacity of the NGOs. We look at general policies of the organizations. We also look at the profiles of the organizations (Interview with an international informant on July 11, 2016 over Skype).

Furthermore, international stakeholders give priority to NGOs which score well in financial and organizational assessments and also consider strongly the quality of the project proposal (Interview with a local informant on June 25, 2016 in Rangamati). But almost all the local informants strongly disagree with these statements by international stakeholders, and their clear-cut opinion is that most of the international stakeholders do not consider the capacity of the organizations. Rather they look at two things: the cost of project implementation and lobbying. As stated by a local interviewee from his first-hand experience:

The UNDP-CHTDF does not consider any expertise or the capacity of local partners and our NGO. We are, therefore, disinterested in the UNDP-CHTDF workshops and decided not to apply for project funding in the future. As an international organization, we did not expect such behavior from the UNDP-CHTDF. But I do not blame the UNDP-CHTDF as a whole, instead I believe some UNDP-CHTDF staff members have diverted and manipulated the UNDP-CHTDF funding in many ways (Interview with a local informant on June 21, 2016 in Bandarban).

\section{Unparallel Power Structure and Marginalized Local Voices}

In spite of having a keen interest in local ownership, local NGOs do not have the institutional, human, material, or financial capacity to carry out their vital roles in 
the post-conflict situation (Shinoda 2008). Almost all local NGOs emerged in the post-Accord period without prior knowledge or experience in running an NGO. In addition, these new NGOs had no clear vision or mission at the beginning (Interview with a local informant on June 23, 2016 in Rangamati). As described by a local informant:

Local NGOs emerged in the CHT without any role model in front of them. They were confused on what kinds of NGOs they want in the region although there are many big national NGOs in Bangladesh like BRAC and Proshika. These NGOs are not suitable to the context of the CHT, although a small number of local NGOs in the CHT have not only taken BRAC, Proshika, and other big national NGOs as ideals, but even named their NGOs to keep consistency with national NGOs (Interview with a local informant on July 3, 2016 in Khagrachhari).

The above statement obviously implies that local NGOs started their interventions in the CHT with a deficiency of knowledge and specialization, and a lack of essential technical skills and organizational capacity to identify needed peacebuilding interventions (Interview with an international informant on July 11, 2016 over Skype; Interview with a local informant on July 2, 2016 in Khagrachhari). For this reason, they decided to work on gender issues, village common forests, and climate change to keep pace with the changing trends of international funding. The most interesting thing is that the interests of donors are not parallel with the local needs of the CHT. For instance, local people do not have access to the market with their agro-products due to the lack of knowledge on marketing and food processing, but they do not get support in this development sector (Interview with a local informant on June 19, 2016 in Bandarban). A respondent told the researcher that:

We do not have peacebuilding strategies since we are entirely donor-driven. We work based on the interests and needs of donors. We are bound to work on the project of violence against women if donors want to work on it. Now we are working on village common forests with donors, but I am surprised when I think why this project is important in the CHT since we have already a culture that emphasizes the preservation of village common forests (Interview with a local informant on June 19, 2016 in Bandarban).

The peacebuilding process of the CHT can be compared with the case of the Democratic Republic of the Congo where international stakeholders focused on rebuilding the state, ignoring local demands for a reconciliation program (Hellmuller 2015). Duckworth (2016) claims that the domestic and political interests of donors took precedence over local priorities in Mali. Libya is also a case where the military and security priorities of donors got preference over local needs. In the view of Adam Curle (1994), this approach marginalizes local 
experts due to super-imposed decisions. An interviewee for this study also reports that staff members of international organizations think they are superior and that local NGOs are their subordinates (Interview with a local informant on June 21, 2016 in Bandarban). Beyond this, workers at donor organizations also underestimate the skills and knowledge of donor-driven local NGOs. As argued by a local respondent:

An international staff member of the World Food Programme (WFP) asked me to give her our project report. When I told her that I shall submit it in English, she was surprised to hear that we are able to write in English. In addition, she could not believe that we can now write a good project report (Interview with a local informant on June 18, 2016 in Bandarban).

In addition, donor organizations lure skilled staff members at local NGOs away with the incentive of a better salary, thus creating a crisis of manpower and organizational strength in local NGOs (Interview with a local informant on June 18, 2016 in Bandarban). But this study does not argue that international donors are in no way dependent on local NGOs. According to a local informant:

We help donors to identify beneficiary project areas based on our indicators such as geographical location (remoteness), government facilities (whether government services are available), presence of NGO activities, distance from the market, the status of women, etc. These indicators help us to identify which village is the most underdeveloped and deserves the project aid (Interview with a local informant on June 19, 2016 in Bandarban).

Without assistance from local NGOs, donors might misperceive the local context due to a lack of information which might consequently reproduce the dynamics of conflict when donors empower some local beneficiaries while leaving others marginalized (Duckworth 2016). In addition, international stakeholders work with local NGOs to reduce the cost of implementing postconflict reconstruction projects. It has been observed that in the case of the FAO, operation costs of projects are very high since it has at least three staff members in each sub-district and spends a large amount of money on salaries, field monitoring, and other official costs related to local workers. Finally, local people get a small portion of the project fund (Interview with a local informant on June 21, 2016 in Bandarban).

\section{Conclusion}

In the view of Brown et al. (2011), post-conflict reconstruction requires a gigantic investment in socio-economic development. Bangladesh, as a developing 
economy, requires external assistance for peacebuilding in the CHT. Pearce (2005), Shinado (2008), and Doyle and Sambanis (2000) have emphasized the importance of local ownership and context-specific demand-driven peacebuilding interventions, but local priorities and needs do not get preference over the interests and motivations of donors in designing the peacebuilding agenda (Duckworth 2016; Futamura and Notaras 2011) as is apparent in the post-conflict reconstruction of Somalia, Burma, Timor-Leste, and Indonesia, just to name a few (Dibley 2014). The CHT also displays the same gloomy image of peacebuilding. The most dominant narratives around peacebuilding in the CHT include one-sided outright dependency (local NGOs are decisionimplementers in most cases while donors are decision-makers), variation in the interests of donors (some focus on education, sanitation, and health issues while others have interest in human rights, good governance, gender issues, etc.), the use of multiple approaches to peacebuilding (bottom-up, mostly top-down, and the hybrid approach), and difficult problems associated with the sustainability of peacebuilding (e.g. lack of demand-driven policy, facilitation problem, etc.). Yet, positive contributions have come from international stakeholders in the peacebuilding of the CHT and these should not be underestimated. Particularly their success is highly discernible in the areas of socio-economic development and community empowerment, although they have failed to achieve their main goals of implementing the CHT Accord and reducing inter-community distrust.

\section{Notes}

1. The term "indigenous" is interchangeably used with Pahari in the CHT (Amnesty International 2013). The indigenous groups living in the CHT include Chakma, Marma, Tripura, Bawm, Chak, Khumi, Khyang, Mru, Lusai, Uchay, Pankho, and Tanchangya (Roy 2000, 19).

2. The European Union (EU) is the top contributor with a donation worth 59 percent of the entire UNDP-CHTDF budget. Among many international organizations, the United Nations Development Programme (UNDP), the United Nation's Children Fund (UNICEF), the Food and Agricultural Organization (FAO), the Canadian International Development Agency (CIDA), the Danish International Development Agency (DANIDA), the Australian Agency for International Development (AusAID), the Japan International Cooperation Agency (JICA), the Norwegian Agency for Development Cooperation (NORAD), the United States Agency for International Development (USAID), and the Asian Development Bank (ADB) have been working on peacebuilding in the CHT since the Accord (Interviews with key persons and managerial staff members of local NGOs and international organizations, June 16 - July 14, 2016).

3. The apex decision-making institutions of the CHT are the Ministry of Chittagong Hill Tracts Affairs (MoCHTA), the Chittagong Hill Tracts Regional Council (CHTRC), the three Hill District Councils (HDCs), and three traditional leadership institutions. 
4. Raj Purna is the traditional festival of the Mong and Bomang circles with the objective to collect taxes from the local people under their jurisdiction.

5. Headman is the second layer of the traditional administrative system. S/he governs a mouza composed of several villages.

6. Karbari is the head of the village who governs the issues of family disputes, land disputes, and minor crimes that take place in his/her territorial jurisdiction. This position is generally conferred by inheritance, but with the approval of the Chief of the Circle.

\section{References}

Ahsan, Aziz-al, and Bhumitra Chakma. 1989. "Problems of National Integration in Bangladesh: the Chittagong Hill Tracts." Asian Survey 29 (10): 959-970.

Amnesty International. 2013. "Pushed to the Edge: Indigenous Rights Denied in Bangladesh's Chittagong Hill Tracts.” http://www.iwgia.org/iwgia_files_news_ files/0812_amnestyCHT.pdf (accessed July 23, 2016).

Autesserre, Severine. 2014. Peaceland: Conflict Resolution and the Everyday of Politics in International Intervention. Cambridge: Cambridge University Press.

Azad, Abid. 2015. "Violence and Land Grabbing Forced 210 Indigenous Families to Flee the Country in 2014." Dhaka Tribune, February 28.

Barakat, Abul, Avijit Podder, Md. Badiuzzaman, and Asmar Osman. 2008. Socio-economic Baseline Survey of Chittagong Hill Tracts. Dhaka: Human Development Research Center.

Boyce, James. 2004. “The International Financial Institutions: Post-conflict Reconstruction and Peacebuilding Capacities." http://www.peri.umass.edu/fileadmin/pdf/Boyce_-_ IFIs__peacebuilding_-_June_20_1_...pdf (accessed August 2, 2016).

Brabant, K. Van. 2010. "Peacebuilding How? Broad Local Ownership." http://dmeforpeace. org/sites/default/files/2010_IP_Peacebuilding_How_Broad_Local_Ownershi (accessed August 28, 2016).

Brown, Graham, Arnim Langer, and Frances Stewart. 2011. "A Typology of Post-Conflict Environments.” https://soc.kuleuven.be/crpd/files/working-papers/wp01.pdf (accessed August 24, 2016).

Cady, Sara. 2014. "Peacebuilding in Palestine Civil Society: Influencing a Peace Process from the Bottom-up." Peace and Conflict Review 8 (1): 97-124.

Chakma, Ashok Kumar. 2013. An Assessment of the UNDP-CHTDF Project on Promotion of Development and Confidence Building in the Chittagong Hill Tracts Relating to the Implementation of the CHT Accord 1997. Rangamati: Maleya Foundation.

Chakma, Bhumitra. 2010. "The Post-Colonial State and Minorities: Ethnocide in the Chittagong Hill Tracts, Bangladesh.” Commonwealth and Comparative Politics 48 (3): 281-300.

Chittagong Hill Tracts Commission. 1991. "Life Is Not Ours: Land and Human Rights in the Chittagong Hill Tracts Bangladesh.” http://www.iwgia.org/publications/searchpubs?publication_id=129 (accessed July 27, 2016).

Cunnington, John, Annette Englert, Md. Ayub Ali, and Mathura B. Tripura. 2014. "Evaluation of Promotion of Development and Confidence Building in the 
Chittagong Hill Tracts Development Facilities." https://info.undp.org/docs/pdc/ Documents/BGD/2014\%20Development\%20Partners\%20Evaluation\%20Report\%20 of\%20CHTDF.pdf (accessed July 20, 2016).

Curle, Adam. 1994. "New Challenges for Citizen Peacemaking." Medicine and War 10: 96105.

Cutillo, Alberto. 2007. "Reviewing Fifteen Years of Peacebuilding: Past, Present and Future of International Assistance to Countries Emerging from Conflicts and Italy's Contribution." University of Trento, Working Paper 01/2007. http://web.unitn.it/files/ download/9722/wpcutillo.pdf (accessed July 27, 2016).

Dibley, Thushara. 2014. Partnerships, Power and Peacebuilding: NGOs as Agents of Peace in Aceh and Timor-Leste. London: Palgrave MacMillan.

Doyle, Michael W., and Nicholas Sambanis. 2000. "International Peacebuilding: A Theoretical and Quantitative Analysis." American Political Science Review 94 (4): 779801.

Duckworth, Cheryl Lynn. 2016. "Peacebuilding Donor-driven? Inside the Dynamics and Impacts of Funding Peace." Journal of Peacebuilding and Development 11 (1): 5-9.

Futamura, Madoka, and Mark Notaras. 2011. "Local Perspectives on International Peacebuilding." United Nations University, June 7. https://unu.edu/publications/ articles/local-perspectives-on-international-peacebuilding.html\#info (accessed July 26, 2016).

Gerharz, Eva. 2002. "Dilemmas in Planning Crisis Prevention: NGOs in the Chittagong Hill Tracts of Bangladesh." Journal of Social Studies 97: 19-36.

Mac Ginty, Roger. 2011. International Peacebuilding and Local Resistance: Hybrid Form of Peace. New York: Palgrave MacMillan.

Gruener, Sigrid, and Matilda Hald. 2015. "Local Perspectives on Inclusive Peacebuilding: A Four-country Study.” Dag Hammarskjöld Foundation, Development Dialogue Paper No. 13, May. http://www.daghammarskjold.se/wp-content/uploads/2015/05/ddpaper_no13web.pdf (accessed July 29, 2016).

Haider, Huma. 2009. "Community-based Approaches to Peacebuilding in ConflictAffected and Fragile Contexts." Governance and Social Development Resource Centre, Issues Paper, November. http://www.gsdrc.org/docs/open/eirs8.pdf (accessed May 22, 2016).

Hammersley, Martyn, and Roger Gomm. 2008. "Assessing the Radical Critique of Interviews." In Questioning Qualitative Inquiry: Critical Essays, ed. Martyn Hammersley, 89-100. Los Angeles: Sage.

Haq, Selina, and Ehsanul Hoque. 1990. Disintegration Process in Action: the Case of South Asia. Dhaka: Bangladesh Institute of Law and International Affairs.

Hellmuller, Sara. 2014. "International and Local Actors in Peacebuilding: Why Don't They Cooperate?” Swiss Peace, Working Paper, April. http://www.swisspeace.ch/fileadmin/ user_upload/Media/Publications/WP_4_2014.pdf (accessed September 22, 2016).

Hellmuller, Sara. 2015. "Timing and Sequencing of Post-Conflict Reconstruction and Peacebuilding Efforts in DR Congo." https://soc.kuleuven.be/crpd/files/workingpapers/working-paper-hellmuller.pdf (accessed October 19, 2017).

Hossain, Dewan Mahboob. 2013. "Socio-economic Situations of Indigenous Peoples of the Chittagong Hill Tracts (CHT) of Bangladesh.” Middle East Journal of Business 8 (2): 22-30. 
Lederach, John Paul. 1997. Building Peace: Sustainable Reconciliation in Divided Societies. Washington, D.C.: United States Institute of Peace.

Maleya Foundation. 2014. "Village Common Forest (VCF) Conservation and Management is the Daily-life Necessity for Indigenous Villagers of CHT." http://www.maleya.org/ index.php/we-work-on/environment-and-forest (accessed August 4, 2016).

Mohsin, Amena. 1999. The Politics of Nationalism: the Case of the Chittagong Hill Tracts, Bangladesh. Dhaka: Dhaka University Press.

Mohsin, Amena. 2003. The Chittagong Hill Tracts, Bangladesh: On the Difficult Road to Peace. London: Lynne Rienner Publishers.

OECD. 1997. "Conflict, Peace and Development Co-operation on the Threshold of the 21st Century." http://pdf.usaid.gov/pdf_docs/Pcaaa817.pdf (accessed October 16, 2017).

Paris, Roland. 2004. At War's End: Building Peace After Civil Conflict. Cambridge: Cambridge University Press.

Pearce, Jenny. 2005. “The International Community and Peacebuilding." Development 48 (3): 41-49.

Peou, Sorpong. 2014. "The Limits and Potential of Liberal Peacebuilding for Human Security." Asian Journal of Peacebuilding 2 (1): 37-60.

Roy, Rajkumari Chandra. 2000. "Land Rights of the Indigenous Peoples of the Chittagong Hill Tracts, Bangladesh.” International Work Group for Indigenous Affairs, Document No. 99. http://www.iwgia.org/iwgia_files_publications_files/0128_Chittagong_hill_ tracts.pdf (accessed May 10, 2017).

Reich, Hannah. 2006. "'Local Ownership' in Conflict Transformation Projects: Partnership, Participation or Patronage?” Berghof Research Center for Constructive Conflict Management, Occasional Paper No. 27, September. http://www.berghof-foundation. org/fileadmin/redaktion/Publications/Papers/Occasional_Papers/boc27e.pdf (accessed August 22, 2016).

Shinoda, Hideaki. 2008. "The Difficulty and Importance of Local Ownership and Capacity Development in Peacebuilding." Hiroshima Peace Science 30: 95-115.

Tschirgi, Necla. 2004. "Post-Conflict Peacebuilding Revisted: Achievements, Limitations and Challenges." WSP International/IPA Peacebuilding Forum Conference, New York, October 7. http://reliefweb.int/sites/reliefweb.int/files/resources/17F10390968 04EA78525742D005B17F9-IPA_Post-Conflict_Peacebuilding_Oct04.pdf (accessed August 8, 2016).

UN (United Nations) Secretary-General. 2009. "Report on the Secretary-General on Peacebuilding in the Aftermath of Conflict." http://www.un.org/en/peacebuilding/ pbso/pdf/s2009304.pdf (accessed October 15, 2017).

UNDP-CHTDF (United Nations Development Programme-Chittagong Hill Tracts Development Facility). 2014. "Annual Report on Promotion of Development and Confidence Building in the Chittagong Hill Tracts.” http://www.bd.undp.org/ content/bangladesh/en/home/operations/projects/crisis_prevention_and_recovery/ chittagong-hill-tracts-development-facility.html (accessed July 20, 2016).

Yeo, Alice, Robin Legard, Jill Keegan, Kit Ward, and Carol McNaughton Nicholls. 2003. "In-depth Interviews." In Qualitative Research Practice: A Guide for Social Science Students and Researchers, eds. Jane Ritchie, Jane Lewis, Carol McNaughton Nicholls, and Rachel Ormston. London, Thousand Oaks, and New Delhi: Sage.

Zahed, Iqthyer Uddin Md. 2013. "Conflict between the Government and the Indigenous 
Peoples of the Chittagong Hill Tracts in Bangladesh." IOSR Journal of Humanities and Social Sciences 16 (5): 97-102.

Anurug Chakma is an Assistant Professor in the Department of Peace and Conflict Studies at the University of Dhaka. He completed his undergraduate and graduate degrees in Peace and Conflict Studies at the University of Dhaka. In addition, he obtained his Masters in Governance and Development from the University of Antwerp under the VLIR-UOS scholarship program. He previously was a researcher at the Bangladesh Legal Aid and Services Trust (BLAST). Furthermore, he has worked with the UNDP-CHTDF as a researcher and national consultant for the last three years.

Submitted: November 21, 2016; Revised: May 15, 2017; Accepted: July 5, 2017 